\title{
Cross-Metathesis Approach for Stereocontrolled Synthesis of the C1-C15 Fragment of Rhizopodin
}

\author{
Honggang Gui, ${ }^{a}$ Junyang Liu, ${ }^{\mathrm{a}, \mathrm{b}}$ Liankai Song, ${ }^{\mathrm{a}}$ Chunngai Hui, ${ }^{\mathrm{b}}$ Junmin Feng, ${ }^{a}$ Zhengshuang $\mathrm{Xu},{ }^{* a}$ Tao Ye*b \\ ${ }^{a}$ Laboratory of Chemical Genomics, Peking University Shenzhen Graduate School, University Town of Shenzhen, Xili, Nanshan District, \\ Shenzhen, 518055, P. R. of China \\ b Department of Applied Biology \& Chemical Technology, The Hong Kong Polytechnic University, Hung Hom, Kowloon, Hong Kong, \\ P. R. of China \\ Fax +852(2)2641912; E-mail: tao.ye@polyu.edu.hk; E-mail: xuzs@pkusz.edu.cn \\ Received: 18.08.2013; Accepted after revision: 22.09.2013
}

\begin{abstract}
The C1-C15 fragment of rhizopodin was synthesized through either Suzuki coupling reaction of vinyl iodide and vinyl boronate or cross-metathesis of a terminal olefin and a diene adduct in the presence of Hoveyda-Grubbs II catalyst.
\end{abstract}

Key words: cross-metathesis, cross-coupling, stereocontrolled synthesis, conjugated diene, rhizopodin

Rhizopodin was isolated by Höfle and Reichenbach from the myxobacterium Myxococcus stipitatus and was assigned as a monomeric lactone in 1993. ${ }^{1}$ Its structure and absolute stereochemistry were recently revised as shown in Scheme 1. ${ }^{2,3}$ Rhizopodin exhibits significant biological properties including potent cytostatic activity in the low nanomolar range against a range of tumor cell lines. ${ }^{1-3}$ The distinctive structural features and biological activities, together with our interest in macrocyclic marine natural products ${ }^{4}$ prompted us to undertake studies on the synthesis of rhizopodin. Recently, various synthetic approaches toward the synthesis of rhizopodin have been reported..$^{5}$ The syntheses of monorhizopodin and 16-epimonorhizopodin were achieved by Nicolaou and coworkers in $2011^{5 \mathrm{e}}$ and, since then, two total syntheses of rhizopodin have been reported. ${ }^{5 \mathrm{~g}, \mathrm{j}}$

So far, total syntheses of the macrocycle of rhizopodin have employed either intramolecular Suzuki coupling reaction or macrolactonization. ${ }^{5 \mathrm{~g}-\mathrm{j}}$ An alternative approach to the macrocyclizations was sought and we opted to close the macrocyclic core by ene-diene cross-metathesis ${ }^{6}$ as shown in our retrosynthetic plan (Scheme 1). To test the feasibility of the key ene-diene cross-metathesis step of our designed strategy toward rhizopodin, a model study based on the construction of the $\mathrm{C} 1-\mathrm{C} 15$ fragment (1) of rhizopodin was undertaken. Herein we detail two synthetic approaches to fragment $\mathbf{1}$.

Retrosynthetic analysis of $\mathbf{1}$ led us to disconnect between positions C8 and C9, which imposed the construction of the conjugated diene through cross-metathesis of frag-

SYNLETT 2014, 25, 0138-0142

Advanced online publication: 05.11.2013

DOI: 10.1055/s-0033-1340154; Art ID: ST-2013-W0795-L

(C) Georg Thieme Verlag Stuttgart · New York ments 2 and 3. Alternatively, a Suzuki cross-coupling of vinyl boronate 4 with vinyl iodide 5 was envisioned to deliver diene 1 (Scheme 1). Oxazole-containing fragments 2 and 4 were planned to originate from the common precursor 10, which, in turn, would be prepared from the known methyl-2-(chloromethyl)oxazole-4-carboxylate (7; Scheme 2).

The synthesis of fragments $\mathbf{2}$ and $\mathbf{4}$ is outlined in Scheme 2. Oxazole 7 was obtained from commercially available 2,2-dichloronitrile (6) by using a known sequence. ${ }^{7}$ Reaction of 7 with sodium acetate in the presence of acetic acid and acetic anhydride and treatment of the resultant acetate derivative with potassium carbonate and methanol afforded the corresponding alcohol 8 in $61 \%$ yield over two steps. After protection of the primary alcohol as its TBS ether, the methyl ester was reduced with DIBAL-H in THF to give alcohol 9 in $84 \%$ yield. This route is operationally convenient and proceeds well on large scale ( $>35 \mathrm{~g}$ of 9 was obtained). It should be mentioned that alcohol 9 could be obtained by a reported procedure $;{ }^{8}$ however, in our hands, we were unable to reproduce the reaction on large scales. Swern oxidation ${ }^{9}$ of the primary alcohol of 9 , followed by Keck allylation ${ }^{10}$ of the resulting aldehyde, provided homoallylic alcohol 10 in $72 \%$ yield with $>97 \%$ enantiomeric excess, as measured on its Mosher ester. ${ }^{11}$ The absolute stereochemistry at the newly created stereogenic center was also assigned at this point by synthesis and comparison of the ${ }^{1} \mathrm{H}$ NMR spectra of its Mosher derivatives. ${ }^{12}$ Thus, homoallylic alcohol $\mathbf{1 0}$ was reacted with both $(S)$ - and $(R)$ - $\alpha$-methoxy- $\alpha$-(trifluoromethyl)phenylacetic acid to generate diastereomeric $(S)$ or $(R)$-Mosher esters $\mathbf{1 2}$ and $\mathbf{1 3}$, respectively (Table 1 ). Subtraction of the chemical shifts of the protons of $(R)$ Mosher ester 13 from those of $(S)$-Mosher ester 12 in the vicinity of the ester-bearing stereocenter then provides differences $(\Delta \delta)$, the signs of which are used to assign the configuration of the stereocenter. The signs of the $\Delta \delta$ are shown in Table 1, and the absolute stereochemistry at $\mathrm{C} 11$ was elucidated to be the $(S)$-configuration.

$O$-Methylation of the homoallylic alcohol 10 by using iodomethane and sodium hydride in THF provided 2 in $84 \%$ yield. Olefin cross-metathesis between $\mathbf{2}$ and vinyl pinacol boronate 11 under the influence of the Hoveyda- 


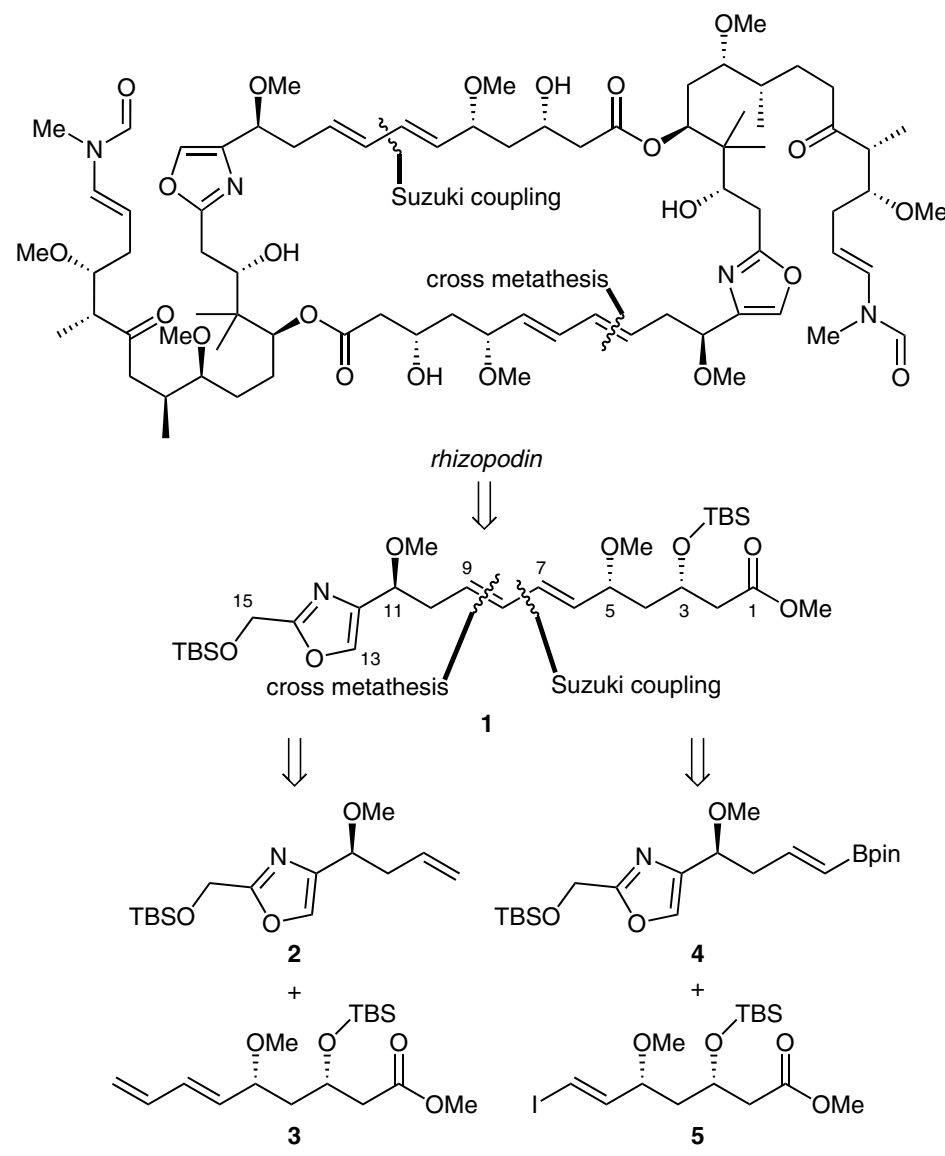

Scheme 1 Retrosynthetic analysis

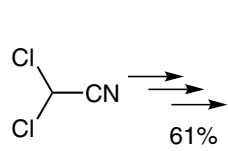

6<smiles>C=CCC(O)c1coc(COC(C)(C)C)n1</smiles><smiles>[3H][13C](C)(C)C</smiles><smiles>C=CCC(OC)c1coc(COC(C)(C)C)n1</smiles>
TBSO

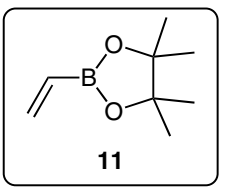<smiles>COC(CC=CB1OC(C)(C)C(C)(C)O1)c1coc(CO[13CH3])n1</smiles>

Scheme 2 Preparation of intermediates 2 and 4. Reagents and conditions: (i) $\mathrm{NaOAc}, \mathrm{HOAc}-\mathrm{Ac}_{2} \mathrm{O}$; (ii) $\mathrm{K}_{2} \mathrm{CO}_{3}, \mathrm{MeOH}$; (iii) $\mathrm{TBSCl}$, imidazole, $\mathrm{CH}_{2} \mathrm{Cl}_{2}$; (iv) DIBAL-H, THF; (v) $(\mathrm{COCl})_{2}, \mathrm{DMSO}_{2} \mathrm{Et}_{3} \mathrm{~N}$, $\mathrm{CH}_{2} \mathrm{Cl}_{2},-78^{\circ} \mathrm{C}$; (vi) $(S)$-BINOL, Ti(O $i$-Pr $)_{4}$, allyltributylstannane, $\mathrm{CH}_{2} \mathrm{Cl}_{2},-20^{\circ} \mathrm{C}, 72 \mathrm{~h}$; (vii) NaH, MeI, THF; (viii) 11, HoveydaGrubbs II catalyst, toluene, $80^{\circ} \mathrm{C}$.
Grubbs II catalyst furnished vinyl boronate 4 in $65 \%$ yield $\left(E / Z=10: 1 ;\right.$ Scheme 2) ${ }^{13}$

The preparation of coupling partners $\mathbf{3}$ and $\mathbf{5}$ commenced from methyl ester 14, which was prepared according to conditions described by Paterson ${ }^{14}$ (Scheme 3). Methyl ester 14 was reduced to aldehyde 15 in $94 \%$ yield by using DIBAL-H in dichloromethane. Subsequent treatment of 15 with $\beta$-(+)-allyldiisopinocampheylborane according to Brown et al. ${ }^{15}$ provided a 10:1 mixture of syn- and antimonomethylated diols, favoring the desired isomer, which was protected as its TBS ether 16 (55\% yield over two steps). Oxidative cleavage of the terminal olefin by using the Sharpless protocol, ${ }^{16}$ and esterification of the resultant acid with trimethylsilyldiazomethane ${ }^{17}$ provided methyl ester 17 in $63 \%$ yield over two steps. Selective removal of the primary TBS group in the presence of the secondary TBS group under mild acidic conditions provided alcohol 18 in $88 \%$ yield. Oxidation of the primary alcohol in 18 by using the Dess-Martin periodinane reagent ${ }^{18}$ buffered with sodium bicarbonate afforded the corresponding aldehyde, which served as the precursor leading to both 3 and 5. Thus, a Horner-WadsworthEmmons olefination between the diethyl allylphosphonate and the aldehyde derived from 18 successfully led to the required diene 3 in 53\% yield and good $E / Z$ selectivity $(15: 1)$. In parallel, treatment of the aldehyde with iodo- 
Table 1 Stereochemical Assignment of $\mathbf{1 0}^{\mathrm{a}}$

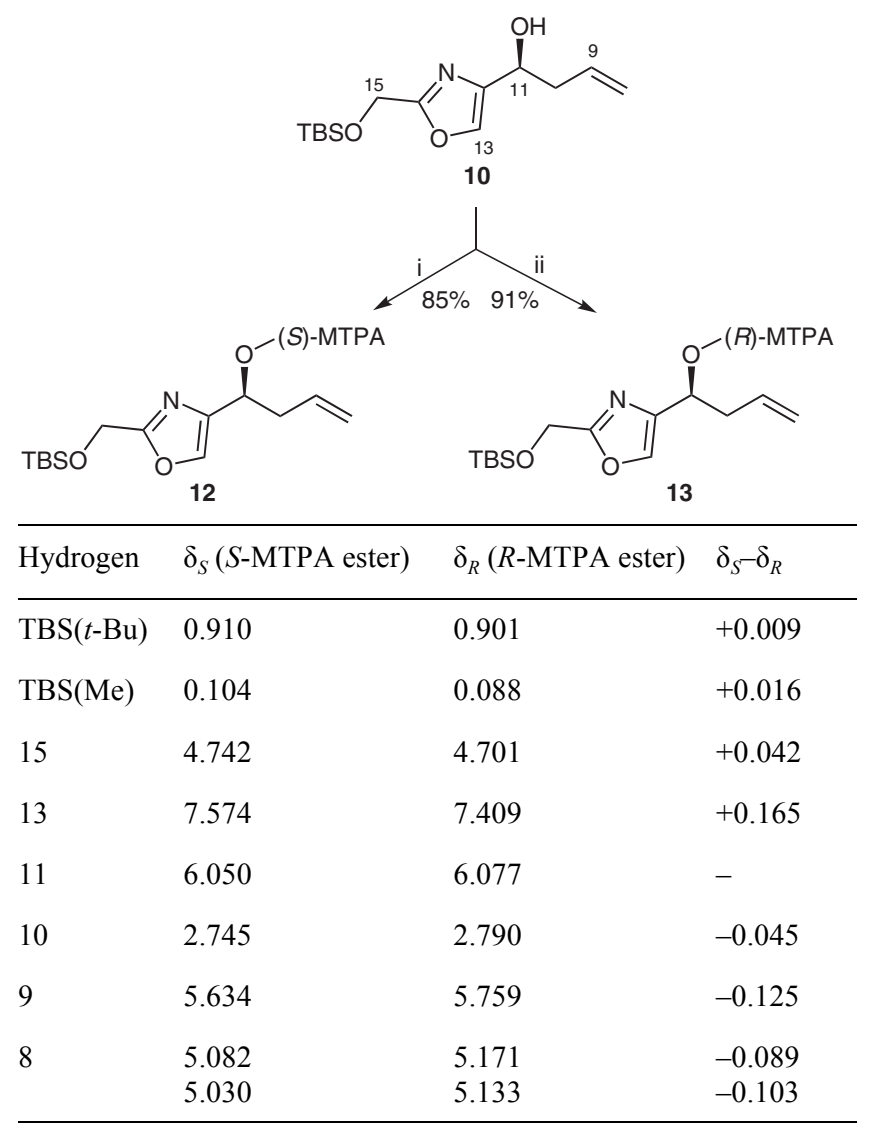

${ }^{a}$ Reaction conditions: (i) oxallyl chloride, DMF, $\mathrm{CH}_{2} \mathrm{Cl}_{2},(S)$-MTPA; then $\mathrm{Et}_{3} \mathrm{~N}$, DMAP, $\mathrm{CH}_{2} \mathrm{Cl}_{2}, \mathbf{1 0}, 85 \%$; (ii) oxallyl chloride, DMF, $\mathrm{CH}_{2} \mathrm{Cl}_{2},(R)$-MTPA; then $\mathrm{Et}_{3} \mathrm{~N}$, DMAP, $\mathrm{CH}_{2} \mathrm{Cl}_{2}, \mathbf{1 0}, 91 \%$.

form and chromous chloride in $\mathrm{THF}^{19}$ gave vinyl iodide $\mathbf{5}$ in $63 \%$ overall yield with greater than $10: 1 E / Z$ selectivity. With the four requisite fragments $\mathbf{2}-\mathbf{5}$ in hand, the stage was set to test the palladium-catalyzed cross-coupling reaction (Table 2) and ene-diene cross-metathesis (Table 3). First, we explored the Suzuki coupling reaction ${ }^{20}$ of vinyl boronate $\mathbf{4}$ and vinyl iodide 5 under various conditions. Initially the widely used protocol was employed using $\left[\mathrm{Pd}\left(\mathrm{Ph}_{3} \mathrm{P}\right)_{4}\right]-\mathrm{Ph}_{3} \mathrm{As}$ and $\mathrm{Cs}_{2} \mathrm{CO}_{3}$ in THF. Unfortunately, the desired product 1 was obtained in only $35 \%$ isolated yield (Table 2, entry 1 ). When the catalyst was switched to $\left[\mathrm{Pd}(\mathrm{dppf})_{2} \mathrm{Cl}_{2}\right]$, diene $\mathbf{1}$ was isolated in a much improved yield (52\%; entry 2 ). Further optimization of the catalytic systems led to the identification of a remarkably simple protocol, in which vinyl boronate $\mathbf{4}$ and vinyl iodide 5 were exposed to $\left[\mathrm{Pd}\left(\mathrm{Ph}_{3} \mathrm{P}\right)_{4}\right]$ and TlOEt in $\mathrm{THF}-\mathrm{H}_{2} \mathrm{O}(\mathrm{v} / \mathrm{v} 4: 1)$ to furnish 1 in $73 \%$ isolated yield (entry 3 ). ${ }^{21}$

We then examined the key ene-diene cross-metathesis reaction under several conditions by varying the solvent, catalyst, and temperature. As shown in Table 3, initial cross-metathesis of alkene $\mathbf{2}$ and diene 3 at $80^{\circ} \mathrm{C}$ in toluene with Grubbs I catalyst provided no conversion (entry 1). Furthermore, attempts to mediate the cross-metathesis
Table 2 Suzuki Coupling for the Synthesis of Diene $\mathbf{1}^{\mathrm{a}}$

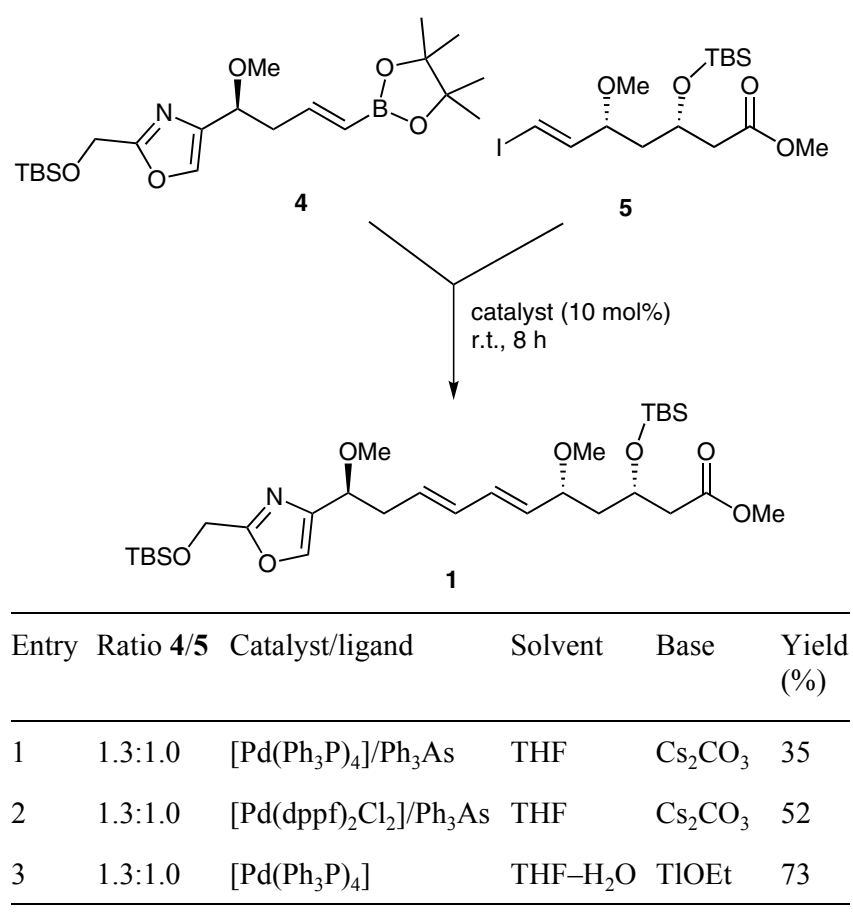

${ }^{a}$ Reaction conditions: See table and text for details.

with $10 \mathrm{~mol} \%$ of either Grubbs II catalyst or HoveydaGrubbs II catalyst in dichloromethane at reflux also failed to provide any detectable quantities of diene 1 . Fortunately, performing this reaction at $60^{\circ} \mathrm{C}$ in toluene with Grubbs II catalyst or Hoveyda-Grubbs II catalyst, afforded 1 in $24 \%$ and $40 \%$ yield, respectively (entries 4 and 5).

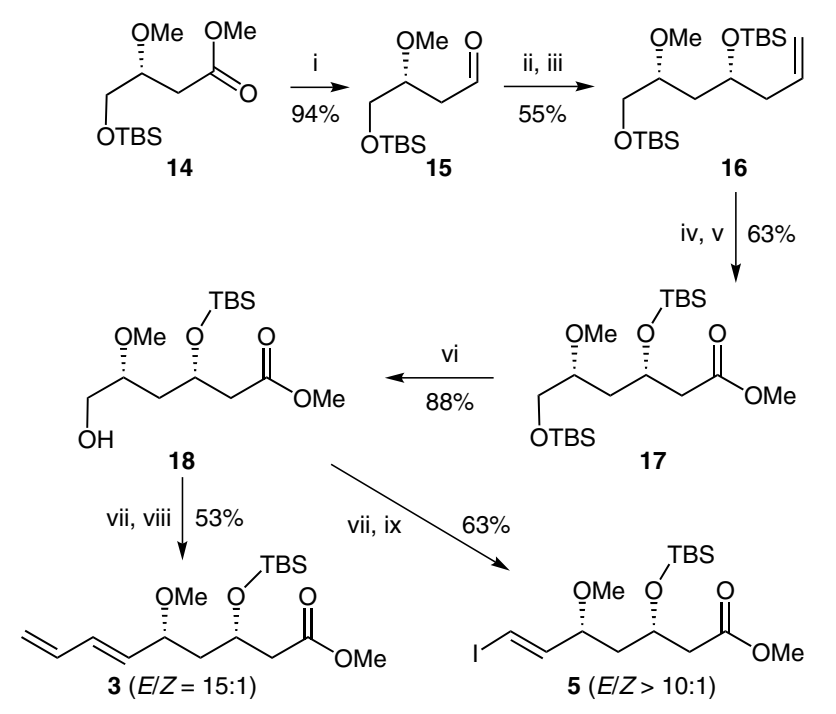

Scheme 3 Preparation of intermediates 3 and 5 . Reagents and conditions: (i) DIBAL-H, $\mathrm{CH}_{2} \mathrm{Cl}_{2},-78^{\circ} \mathrm{C}$; (ii) (+)-Ipc ${ }_{2} \mathrm{BOMe}$, allylmagnesium bromide, $\mathrm{Et}_{2} \mathrm{O}, 0$ to $-78{ }^{\circ} \mathrm{C}$; then 15; (iii) $\mathrm{TBSCl}, \mathrm{Et}_{3} \mathrm{~N}$, DMAP, $\quad \mathrm{CH}_{2} \mathrm{Cl}_{2} ; \quad$ (iv) $\mathrm{RuCl}_{3}, \quad \mathrm{NaIO}_{4}, \quad \mathrm{CCl}_{4}-\mathrm{MeCN}-\mathrm{H}_{2} \mathrm{O}$; (v) $\mathrm{TMSCHN}_{2}, \mathrm{MeOH}$; (vi) (-)-CSA, $\mathrm{CH}_{2} \mathrm{Cl}_{2}-\mathrm{MeOH}$; (vii) DessMartin periodinane, $\mathrm{NaHCO}_{3}, \mathrm{CH}_{2} \mathrm{Cl}_{2}$; (viii) diethyl allylphosphonate, $n \mathrm{BuLi}$, HMPA, THF, $-78^{\circ} \mathrm{C}$, then aldehyde; (ix) $\mathrm{CrCl}_{2}, \mathrm{CHI}_{3}$, THF. 
Furthermore, by increasing the reaction temperature to $80^{\circ} \mathrm{C}$ in toluene in the presence of Hoveyda-Grubbs II catalyst, the yield improved considerably, and diene $\mathbf{1}$ could be isolated in $51 \%$ yield $^{21}$ as the $(E, E)$-alkene, the conformation of which was determined by ${ }^{1} \mathrm{H}$ NMR spectroscopic analysis. Considering the thermal stability of both starting material and catalyst, attempts to further improve the yield by the use of elevated temperatures were not conducted.

Table 3 Cross-Metathesis of Alkene 2 and Diene $3^{\text {a }}$

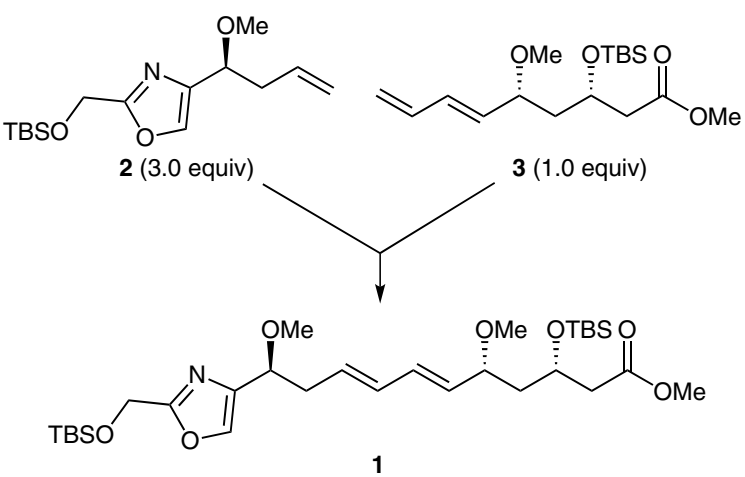

\begin{tabular}{lllll}
\hline Entry & Catalyst $(10 \mathrm{~mol} \%)$ & Solvent & Temp $\left({ }^{\circ} \mathrm{C}\right)$ & Yield $(\%)^{\mathrm{b}}$ \\
\hline 1 & Grubbs I & toluene & 80 & - \\
2 & Grubbs II & $\mathrm{CH}_{2} \mathrm{Cl}_{2}$ & 40 & - \\
3 & Hoveyda-Grubbs II & $\mathrm{CH}_{2} \mathrm{Cl}_{2}$ & 40 & - \\
4 & Grubbs II & toluene & 60 & 24 \\
5 & Hoveyda-Grubbs II & toluene & 60 & 40 \\
6 & Hoveyda-Grubbs II & toluene & 80 & 51 \\
\hline
\end{tabular}

${ }^{a}$ Reaction conditions: See table and text for details.

${ }^{\mathrm{b}}$ Yield based on recovered $\mathbf{3}$.

In summary, the $\mathrm{C} 1-\mathrm{C} 15$ fragment of rhizopodin was synthesized by either Suzuki coupling reaction of vinyl iodide and vinyl boronate or by cross-metathesis of a terminal olefin and a diene adduct in the presence of HoveydaGrubbs II catalyst. This study demonstrates the effectiveness of an ene-diene cross-metathesis approach to diene $\mathbf{1}$ and served as a model study for the total synthesis of rhizopodin based on ene-diene cross-metathesis strategy. Further efforts directed toward the asymmetric total synthesis of rhizopodin and its analogues are underway and will be reported in due course.

\section{Acknowledgment}

We acknowledge financial support from the Hong Kong Research Grants Council (Projects: PolyU 5040/10P; PolyU 5037/11P, PolyU 5020/12P; PolyU5030/13P), the Fong Shu Fook Tong Foundation, the Joyce M. Kuok Foundation, the NSFC (21072007, 21272011), GDSFC (10151805704000005), and The Shenzhen Bureau of Science, Technology and Information (JC200903160367A, JC201005260220A, JC201005260102A, ZYC201105170351A).
Supporting Information for this article is available online at http://www.thieme-connect.com/ejournals/toc/synlett.

\section{References and Notes}

(1) Sasse, F.; Steinmetz, H.; Höfle, G.; Reichenbach, H. J. Antibiot. 1993, 46, 741.

(2) (a) Jansen, R.; Steinmetz, H.; Sasse, F.; Schubert, W. D.; Hagelüken, G.; Albrecht, S. C.; Müller, R. Tetrahedron Lett. 2008, 49, 5796. (b) Horstmann, N.; Menche, D. Chem. Commun. 2008, 41, 5173.

(3) Hagelueken, G.; Albrecht, S. C.; Steinmetz, H.; Jansen, R.; Heinz, D. W.; Kalesse, M.; Schubert, W. D. Angew. Chem. Int. Ed. 2009, 48, 595.

(4) (a) Liu, H.; Liu, Y.; Wang, Z.; Xing, X.; Maguire, A. R.; Luesch, H.; Zhang, H.; Xu, Z.; Ye, T. Chem. Eur. J. 2013, 19, 6774. (b) Boyaud, F.; Mahiout, Z.; Lenoir, C.; Tang, S.; Wdzieczak-Bakala, J.; Witczak, A.; Bonnard, I.; Banaigs, B.; Ye, T.; Inguimbert, N. Org. Lett. 2013, 15, 3898. (c) Long, B.; Tang, S.; Chen, L.; Qu, S.; Chen, B.; Liu, J. Y.; Maguire, A. R.; Wang, Z.; Liu, Y.; Zhang, H.; Xu, Z. S.; Ye, T. Chem. Commun. 2013, 49, 2977. (d) Dai, L.; Chen, B.; Lei, H.; Wang, Z.; Liu, Y.; Xu, Z.; Ye, T. Chem. Commun. 2012, 48, 8697. (e) Liu, J.; Ma, X.; Liu, Y.; Wang, Z.; Kwong, S.; Ren, Q.; Tang, S.; Meng, Y.; Xu, Z.; Ye, T. Synlett 2012, 783. (f) Wang, L.; Xu, Z.; Ye, T. Org. Lett. 2011, 13, 2506. (g) Liu, H.; Liu, Y. Q.; Xu, Z. S.; Ye, T. Chem. Commun. 2010, 46, 7486. (h) Gao, X. G.; Liu, Y. Q.; Kwong, S. Q.; Xu, Z. X.; Ye, T. Org. Lett. 2010, 12, 3018. (i) Li, S.; Chen, Z.; Xu, Z. S.; Ye, T. Chem. Commun. 2010 , 46, 4773. (j) Chen, Z.; Song, L.; Xu, Z. S.; Ye, T. Org. Lett. 2010, 12, 2036. (k) Jin, Y.; Liu, Y. Q.; Wang, Z.; Kwong, S.; Xu, Z. S.; Ye, T. Org. Lett. 2010, 12, 1100. (1) Liang, S.; Xu, Z. S.; Ye, T. Chem. Commun. 2010, 46, 153. (m) Chen, B.; Dai, L.; Zhang, H.; Tan, W.; Xu, Z. S.; Ye, T. Chem. Commun. 2010, 46, 574. (n) Li, S.; Liang, S.; Tan, W. F.; Xu, Z. S.; Ye, T. Tetrahedron 2009, 65, 2695. (o) Li, S.; Liang, S.; Xu, Z. S.; Ye, T. Synlett 2008, 569. (p) Ren, Q.; Dai, L.; Zhang, H.; Tan, W.; Xu, Z. S.; Ye, T. Synlett 2008, 2379. (q) Chen, Z. Y.; Ye, T. New J. Chem. 2006, 30, 518. (r) Pang, H. W.; Xu, Z. S.; Chen, Z. Y.; Ye, T. Lett. Org. Chem. 2005, 2, 699. (s) Pang, H. W.; Xu, Z. S.; Ye, T. Lett. Org. Chem. 2005, 2, 703. (t) Chen, H. L.; Xu, Z. S.; Ye, T. Tetrahedron 2005, 61, 11132. (u) Peng, Y. G.; Pang, H. W.; Ye, T. Org. Lett. 2004, 6, 3781. (v) Chen, Z. Y.; Deng, J. G.; Ye, T. ARKIVOC 2003, (vii), 268. (w) Xu, Z. S.; Peng, Y. G.; Ye, T. Org. Lett. 2003, 5, 2821.

(5) (a) Cheng, Z.; Song, L.; Xu, Z.; Ye, T. Org. Lett. 2010, 12, 2036. (b) Chakraborty, T. K.; Pulukuri, K. K.; Sreekanth, M. Tetrahedron Lett. 2010, 51, 6444. (c) Chakraborty, T. K.; Sreekanth, M.; Pulukuri, K. K. Tetrahedron Lett. 2011, 52, 59. (d) Chakraborty, T. K.; Pulukuri, K. K. Org. Lett. 2012, 14, 2858. (e) Nicolaou, K. C.; Jiang, X.; Lindsay-Scott, P. J.; Corbu, A.; Yamashiro, S.; Bacconi, A.; Fowler, V. M. Angew. Chem. Int. Ed. 2011, 50, 1139. (f) Kretschmer, M.; Menche, D. Org. Lett. 2012, 14, 382. (g) Dieckmann, M.; Kretschmer, M.; Li, P.; Rudolph, S.; Herkommer, D.; Menche, D. Angew. Chem. Int. Ed. 2012, 51, 5667.

(h) Dieckmann, M.; Rudolph, S.; Dreisigacker, S.; Menche, D. J. Org. Chem. 2013, 77, 10782. (i) Dieckmann, M.; Menche, D. Org. Lett. 2013, 15, 228. (j) Dalby, S. M.; Goodwin-Tindall, J.; Paterson, I. Angew. Chem. Int. Ed. 2013, 52, 6517.

(6) For the construction of 1,3-dienes through cross-metathesis, see: (a) Funk, T. W.; Efskind, J.; Grubbs, R. H. Org. Lett. 2007, 7, 187. (b) Moura-Letts, G.; Curran, D. P. Org. Lett. 2007, 9, 5. (c) Basu, K.; Eppich, J. C.; Paquette, L. A. Adv. 
Synth. Catal. 2002, 344, 615. (d) Basu, S.; Waldmann, H. J. Org. Chem. 2006, 71, 3977. (e) Lacombe, F.; Radkowski, K.; Seidel, G.; Fürstner, A. Tetrahedron 2004, 60, 7315. For applications in total synthesis of natural macrolides through ene-diene cyclizations, see: (f) Gallenkamp, D.; Fürstner, A. J. Am. Chem. Soc. 2011, 133, 9232. (g) Moulin, E.; Nevado, C.; Gagnepain, J.; Kelter, G.; Fiebig, H. H.; Fürstner, A. Tetrahedron 2010, 66, 6421. (h) Sun, L.; Feng, G.; Guan, Y.; Liu, Y.; Wu, J.; Dai, W. M. Synlett 2009, 2361. (i) Fürstner, A.; Nevado, C.; Tremblay, M.; Chevrier, C.; Teplý, F.; Aïssa, C.; Waser, M. Angew. Chem. Int. Ed. 2006, 45, 5837. (j) Barluenga, S.; Lopez, P.; Mpolin, E.; Winssinger, N. Angew. Chem. Int. Ed. 2004, 43, 3467. (k) Wang, X.; Porco, J. A. Jr. J. Am. Chem. Soc. 2003, 125, 6040. (1) Sedrani, R.; Martin Cabrejas, L. M.; Papageorgiou, C. D.; Senia, F.;

Rohrbach, S.; Wagner, D.; Thai, B.; Eme, A.-M. J.; France, J.; Oberer, L.; Rihs, G.; Zenke, G.; Wagner, J. J. Am. Chem. Soc. 2003, 125, 3849. (m) Yang, Z.-Q.; Danishefsky, S. J. J. Am. Chem. Soc. 2003, 125, 9602. (n) Yamamoto, K.; Garbaccio, R. M.; Stachel, S. J.; Solit, D. B.; Chiosis, G.; Rosen, N.; Danishefsky, S. J. Angew. Chem. Int. Ed. 2003, 42, 1280. (o) Bach, T.; Lemarchand, A. Synlett 2002, 1302. (p) Paquette, L.; Basu, K.; Eppich, J. C.; Hofferberth, J. E. Helv. Chim. Acta 2002, 85, 3033. (q) Biswas, K.; Lin, H.; Njardarson, J. T.; Chappell, M. D.; Chou, T.-C.; Guan, Y.; Tong, W. P.; He, L.; Horwitz, S. B.; Danishefsky, S. J. J. Am. Chem. Soc. 2002, 124, 9825. (r) Garbaccio, R.; Stachel, S. J.; Baeschlin, D. K.; Danishefsky, S. J. J. Am. Chem. Soc. 2001, 123, 10903. (s) Dvorak, C. A.; Schmitz, W. D.; Poon, D. J.; Pryde, D. C.; Lawson, J. P.; Amos, R. A.; Meyers, A. I. Angew. Chem. Int. Ed. 2000, 39, 1664. (t) Wagner, J.; Martin Cabrejas, L. M.; Grossmith, C. E.; Papageorgiou, C.; Senia, F.; Wagner, D.; France, J.; Nolan, S. P. J. Org. Chem. 2000, 65, 9255. (u) Martin Cabrejas, L. M.; Rohrbach, S.; Wagner, D.; Kallen, J.; Zenke, G.; Wagner, J. Angew. Chem. Int. Ed. 1999, 38, 2443.

(7) Hermitage, S. A.; Cardwell, K. S.; Chapman, T.; Cooke, J. W. B.; Newton, R. Org. Process Res. Dev. 2001, 5, 37.

(8) Panek, J. S.; Beresis, R. T. J. Org. Chem. 1996, 61, 6496.

(9) (a) Mancuso, A. J.; Swern, D. Synthesis 1981, 165.

(b) Tidwell, T. T. Synthesis 1990, 857; and references cited therein.

(10) (a) Keck, G. E.; Tarbet, K. H.; Geraci, L. S. J. Am. Chem. Soc. 1993, 115, 8467. (b) Keck, G. E.; Krishnamurthy, D.; Grier, M. C. J. Org. Chem. 1993, 58, 6543.

(11) Dale, J. A.; Mosher, H. S. J. Am. Chem. Soc. 1973, 95, 512.

(12) (a) Ohtani, I.; Kusumi, T.; Kashman, Y.; Kakisawa, H. J. Am. Chem. Soc. 1991, 113, 4092. (b) Mosher, H. S. J. Org. Chem. 1973, 38, 2143.

(13) Morrill, C.; Grubbs, R. H. J. Org. Chem. 2003, 68, 6031.

(14) Paterson, I.; Findlay, A. D.; Noti, C. Chem. Commun. 2008, 6408.

(15) (a) Brown, H. C.; Jadhav, P. K. J. Am. Chem. Soc. 1983, 105, 2092. (b) Brown, H. C.; Bhat, K. S. J. Am. Chem. Soc. 1986,
108, 5919. (c) Racherla, U. S.; Brown, H. C. J. Org. Chem. 1991, 56, 401.

(16) Sharpless, K. B.; Martin, V. S.; Katsuki, T.; Carlsen, P. H. J. J. Org. Chem. 1981, 46, 3936.

(17) Hashimoto, N.; Aoyama, T.; Shioiri, T. Chem. Pharm. Bull. 1981, 29, 1475.

(18) Dess, D. B.; Martin, J. C. J. Org. Chem. 1983, 48, 4155.

(19) Okazoe, T.; Takai, K.; Utimoto, K. J. Am. Chem. Soc. 1987, 109, 951.

(20) Miyaura, N.; Suzuki, A. Chem. Rev. 1995, 95, 2457; and references cited therein.

(21) Procedures for the synthesis of diene 1:

Suzuki Cross-Coupling; General Procedure: Vinyl iodide 5 (1.0 equiv), pinacol boronate 4 (1.2 equiv), base ( 2.0 equiv) and ligand ( 0.5 equiv) were dissolved in degassed THF $(2.0 \mathrm{~mL})$ and palladium catalyst $(0.1$ equiv) dissolved in degassed THF $(1.0 \mathrm{~mL})$ was added by using a cannula. The reaction mixture was stirred at ambient temperature and monitored by TLC. Upon completion of the reaction, it was quenched by addition of sat. aq $\mathrm{NH}_{4} \mathrm{Cl}(10 \mathrm{~mL})$ and filtered through a pad of Celite, eluted with $\mathrm{CH}_{2} \mathrm{Cl}_{2}(10 \mathrm{~mL})$. The filtrate was concentrated to remove volatiles and the aqueous residue was extracted with $\mathrm{CH}_{2} \mathrm{Cl}_{2}(3 \times 30 \mathrm{~mL})$. The combined organic layers were dried over $\mathrm{Na}_{2} \mathrm{SO}_{4}$ and concentrated under vacuum. The residue was purified by flash column chromatography (EtOAc-hexane, 1:4; $R_{f}=$ $0.4)$ to give diene $\mathbf{1}$ as a colorless oil.

Cross-Metathesis; General Procedure: To a solution of alkene 2 (3.0 equiv) and 1,3-diene 3 (1.0 equiv) in degassed solvent $(1.5 \mathrm{~mL})$, ruthenium catalyst ( 0.1 equiv; predissolved in $1.0 \mathrm{~mL}$ degassed solvent) was added by using a cannula, and the reaction mixture was stirred at different temperatures and monitored by TLC. When the reaction reached completion, volatiles were removed under vacuum, and compound 1 was obtained after purification by flash column chromatography (EtOAc-hexane, $1: 4 ; R_{f}=0.4$ ) as a colorless oil. The analytical data of the product were identical those of the main product of the Suzuki coupling reaction.

Analytical Data of 1: $[\alpha]_{\mathrm{D}}{ }^{25}+8.4\left(c 1.1, \mathrm{CHCl}_{3}\right) .{ }^{1} \mathrm{H}$ NMR $\left(500 \mathrm{MHz}, \mathrm{CDCl}_{3}\right): \delta=7.54(\mathrm{~s}, 1 \mathrm{H}), 6.24-5.97(\mathrm{~m}, 2 \mathrm{H})$, $5.77-5.56(\mathrm{~m}, 1 \mathrm{H}), 5.50-5.31(\mathrm{~m}, 1 \mathrm{H}), 4.75(\mathrm{~s}, 2 \mathrm{H}), 4.33-$ $4.14(\mathrm{~m}, 2 \mathrm{H}), 3.70-3.67(\mathrm{~m}, 1 \mathrm{H}), 3.66(\mathrm{~s}, 3 \mathrm{H}), 3.32(\mathrm{~s}$, $3 \mathrm{H}), 3.21(\mathrm{~s}, 3 \mathrm{H}), 2.72-2.59(\mathrm{~m}, 2 \mathrm{H}), 2.58-2.45(\mathrm{~m}, 2 \mathrm{H})$, 1.85 (ddd, $J=13.3,7.9,5.2 \mathrm{~Hz}, 1 \mathrm{H}), 1.66-1.57(\mathrm{~m}, 1 \mathrm{H})$, $0.91(\mathrm{~s}, 9 \mathrm{H}), 0.87(\mathrm{~d}, J=8.7 \mathrm{~Hz}, 9 \mathrm{H}), 0.10(\mathrm{~s}, 6 \mathrm{H}), 0.05$ (s, $3 \mathrm{H}), 0.03(\mathrm{~s}, 3 \mathrm{H}) \cdot{ }^{13} \mathrm{C} \mathrm{NMR}\left(125 \mathrm{MHz}, \mathrm{CDCl}_{3}\right): \delta=172.19$, 162.85, 140.52, 136.03, 132.70, 131.98, 131.81, 129.99, 78.71, 76.08, 66.78, 58.42, 56.86, 55.96, 51.40, 43.40, $42.42,37.79,25.76,18.37,17.93,-4.49,-4.80,-5.39$. HRMS (ESI): $m / z$ [M + Na] calcd for $\mathrm{C}_{30} \mathrm{H}_{55} \mathrm{NO}_{7} \mathrm{Si}_{2} \mathrm{Na}^{+}$: 620.3410; found: 620.3406 . 